\title{
Heavy metal concentrations in soils from a remote oceanic island, Fernando de Noronha, Brazil
}

\author{
SONIA M.B. DE OLIVEIRA ${ }^{1}$, LUIZ C.R. PESSENDA ${ }^{2}$, SUZY E.M. GOUVEIA ${ }^{2}$ \\ and DEBORAH I.T. FAVARO ${ }^{3}$ \\ ${ }^{1}$ Instituto de Geociências, Universidade de São Paulo, Rua do Lago, 562, 05508-080 São Paulo, SP, Brasil \\ ${ }^{2}$ Laboratório de 14C, Centro de Energia Nuclear na Agricultura, Universidade de São Paulo, \\ Av. Centenário, 303, 13416-000 Piracicaba, SP, Brasil \\ ${ }^{3}$ Instituto de Pesquisas Energéticas e Nucleares, LAN-CRPQ, \\ Av. Prof. Lineu Prestes, 2242, Cidade Universitária, 05508-000 São Paulo, SP, Brasil
}

Manuscript received on May 4, 2010; accepted for publication on March 10, 2011

\begin{abstract}
This paper examines the role of parent rock, pedogenetic processes and airborne pollution in heavy metal accumulation in soils from a remote oceanic island, Fernando de Noronha, Brazil. We studied five soil profiles developed from different volcanic rocks. Mineralogical composition and total concentrations of major and trace elements were determined in 43 samples. The obtained concentrations range for heavy metals were: Co: 26-261 ppm; Cu: 35-97 ppm; Cr: 350-1446 ppm; Ni: 114-691 ppm; Zn: 101-374 ppm; Hg: 2-150 ppb. The composition of soils is strongly affected by the geochemical character of the parent rock. Pedogenesis appears to be responsible for the accumulation of $\mathrm{Zn}, \mathrm{Co}$, and, to a lesser extent, of $\mathrm{Ni}$ and $\mathrm{Cu}$, in the upper, $\mathrm{Mn}$ - and organic carbon-enriched horizons of the soil profiles. Pedogenic influence may also explain the relationship observed between $\mathrm{Cr}$ and the $\mathrm{Fe}$. $\mathrm{Hg}$ is likely to have been added to the soil profile by long-range atmospheric transport. Its accumulation in the topsoil was further favoured by the formation of stable complexes with organic matter. Clay minerals do not appear to play an important role in the fixation of heavy metals.
\end{abstract}

Key words: heavy metals, soils, anthropogenic mercury, Fernando de Noronha.

\section{INTRODUCTION}

The distribution of heavy metals in a soil profile is influenced both by parent rock composition and pedogenetic processes, which may cause the accumulation of metals in a specific horizon. For instance, the nutrient cycle of the vegetation can be responsible for the enrichment of transition metals in surface organic horizons (Blaser et al. 2000, Reimann et al. 2007). Mn and $\mathrm{Fe}$ can also play a role in the concentration of trace metals in soils due to the pronounced metal binding properties of their oxides (Kabata-Pendias and Pendias 1992). In addition to natural causes, local and regional

Correspondence to: Sonia Maria Barros de Oliveira E-mail: soniaoli@usp.br anthropogenic sources can also account for metal accumulation in soils. Furthermore, soils can be affected by long-range atmospheric transport of heavy metals (Nriagu 1989), and even in apparently pristine areas signals of airborne pollution can be detected. However, prior to assessing contamination, it is necessary to determine the local pedo-geochemical background of heavy metals (Baize and Sterckeman 2001, Salonen and Kirsti 2007). The geochemical inheritance of the parent rock can be evaluated by comparing soils developed from rocks of distinct composition under similar climatic conditions (Horckmans et al. 2005, Lasheras Adot et al. 2006). On the other hand, the variation of concentrations with depth and the degree of enrichment/ depletion of an element in relation to the parent rock 
in each soil horizon may help to estimate the role of pedogenesis and the extent of atmospheric input in the contamination of soils (Palumbo et al. 2000, Hernandez et al. 2003).

Here we studied five soil profiles developed from volcanic rocks of a remote oceanic island - Fernando de Noronha (FN) - situated in the South Atlantic Ocean. The aims of this study are (1) to assess the influence of the parent rock fingerprint in the composition of FN soils, (2) to determine the extent to which pedogenesis affected the heavy metal distribution within the soil profiles, and (3) to evaluate the possible contamination of FN soils by atmospheric deposition. $\mathrm{FN}$ is particularly suitable for this kind of study because of the variety of lithologies concentrated in a small area, the absence of industrial and other pollutive emissions in the archipelago and its remoteness from continental sources of dust.

\section{MATERIALS AND METHODS}

Fernando de Noronha (FN) is situated at $03^{\circ} 51^{\prime}$ south and $32^{\circ} 25^{\prime}$ west, approximately $400 \mathrm{~km}$ offshore from the Brazilian coast (Fig. 1). This island has an area of $16.9 \mathrm{~km}^{2}$, making up $91 \%$ of the total area of the Fernando de Noronha archipelago, and reaches a maximum elevation of $320 \mathrm{~m}$ above sea level. At present, the climate is tropical, with two well defined seasons: a rainy season from January to August and a dry season for the remaining of the year. The average annual temperature is $25^{\circ} \mathrm{C}$ and the rainfall averages $1400 \mathrm{~mm}$ per year. Climate changes, as well as variations in the sea level, are thought to have occurred during the Pleistocene (Pessenda et al. 2008).

Although first settled around 1770, FN was scarcely inhabited until World War II. Its permanent population now numbers about 2,100. In 1988 about $70 \%$ of the archipelago was declared an environmentally protected area, and facilities for tourists were restricted. Human activity is mainly centered on the northern side of the island where the main village, Remédios, is situated.

\section{Geologic Setting}

The geology and petrography of FN archipelago was first described by Almeida (1955), and is depicted in the simplified geologic map in Figure 1. Rock geochemistry was reported by, among others, Gunn and Watkins (1976), Weaver (1990), Ulbrich et al. (1994) and Lopes and Ulbrich (2006). The main island is composed of two contrasting suites of igneous rocks. The Remédios Formation consists mainly of plugs and domes of phonolite, alkali-trachyte and alkali-basalt, cut by lamprophiric and basanitic dikes emplaced into pyroclastic tuffs. Unconformably overlying the Remédios Formation is the Quixaba Formation, which is dominated by highly mafic nepheline basaltic flows (nepheline basalts or ankaratrites). K/Ar age determinations (Cordani 1970) indicated an interval from 8 to $12 \mathrm{Ma}$ for the older formation, and 1.7-3.0 Ma for the younger one.

\section{SAMPLING}

Soil sampling was performed as part of a previous study aiming to reconstruct the vegetation and climate changes during the Holocene (Pessenda et al. 2008). The soil profiles were identified as Haplic Cambisols according to the World Reference Base Classification System (FAO 1990).

In the present study, 43 soil samples were selected from five soil profiles (Table I). These are referred in this paper as Morro da Quixaba (MQ), Sancho Bay (SB), Mata Ponta Oeste (MP), Ponta de Atalaia (AB), and Leão Beach (LB) sites (Fig. 1). A precise characterization of the bedrock in each site is difficult because there are no unweathered exposure at the bottom of the profiles. For the purposes of this study, the sampling sites have been allocated to three lithological types according to the geological map of Almeida (1955). At MQ, SB and MP sites the bedrock is thought to be the highly mafic alkalic lava flows of the Quixaba Formation (nepheline basalts). The LB sampling site was located near the contact between the above described nepheline basalts and a small dome of alkaline trachyte (Remédios Formation). At the AB site, the soil profile developed from a sill formed by a coarse-grained equivalent of an alkaline undersaturated phonolite (essexite) of the Remédios Formation, cut by a mafic dike.

Soil of the five profiles was sampled systematically at every $10 \mathrm{~cm}$. At the MQ site, a large pit was hand dug down to $3 \mathrm{~m}$, and the soil profile was sampled from 


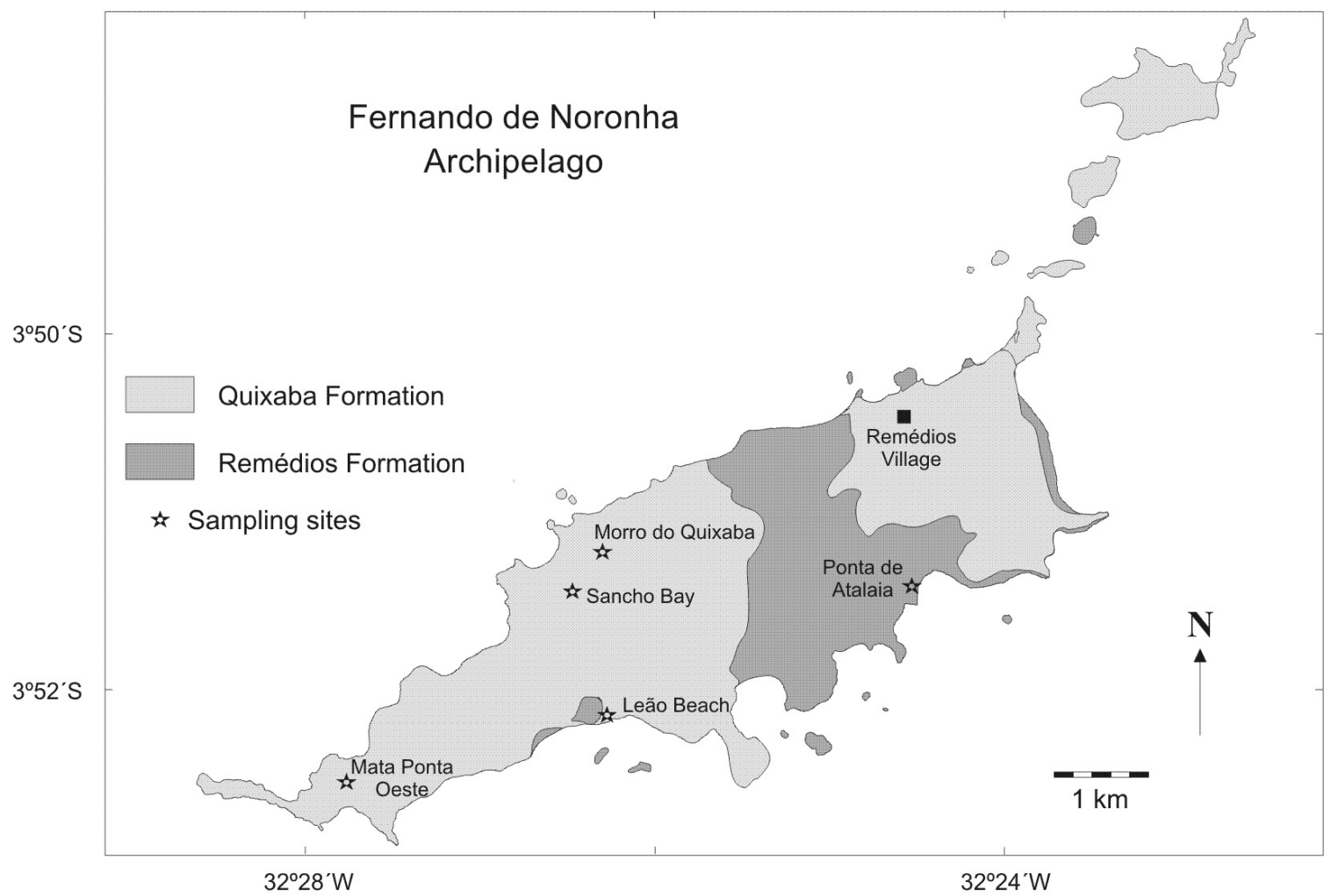

Fig. 1 - Simplified geological map of the Fernando de Noronha archipelago and location of the sampling sites: MQ = Morro do Quixaba; SB = Sancho Bay; MP = Mata Ponta Oeste; $\mathrm{AB}=$ Ponta de Atalaia; LB = Leão Beach.

TABLE I

Description of the sampling sites.

\begin{tabular}{|c|c|c|c|c|c|c|}
\hline Profile & Location & Altitude & Bedrock & Horizon & Depth & Samples \\
\hline \multirow{3}{*}{ MQ } & \multirow{3}{*}{ Morro do Quixaba } & \multirow{3}{*}{$170 \mathrm{~m}$} & \multirow{3}{*}{ Nepheline-basalt } & A & $0-30 \mathrm{~cm}$ & 2 \\
\hline & & & & $\mathrm{A} / \mathrm{B}$ & $31-190 \mathrm{~cm}$ & 8 \\
\hline & & & & $\mathrm{B}$ & $191-290 \mathrm{~cm}$ & 6 \\
\hline \multirow{3}{*}{ SB } & \multirow{3}{*}{ Sancho Bay } & \multirow{3}{*}{$65 \mathrm{~m}$} & \multirow{3}{*}{ Nepheline-basalt } & A & $0-30 \mathrm{~cm}$ & 3 \\
\hline & & & & $\mathrm{B}$ & $31-110 \mathrm{~cm}$ & 4 \\
\hline & & & & $\mathrm{B} / \mathrm{C}$ & $111-140 \mathrm{~cm}$ & 3 \\
\hline \multirow{2}{*}{ MP } & \multirow{2}{*}{ Mata Ponta Oeste } & \multirow{2}{*}{$100 \mathrm{~m}$} & \multirow{2}{*}{ Nepheline-basalt } & $\mathrm{A}$ & $0-30 \mathrm{~cm}$ & 3 \\
\hline & & & & $\mathrm{B}$ & $31-120 \mathrm{~cm}$ & 5 \\
\hline \multirow{2}{*}{$\mathrm{AB}$} & \multirow{2}{*}{ Ponta de Atalaia } & \multirow{2}{*}{$0 \mathrm{~m}$} & \multirow{2}{*}{ Essexite } & $\mathrm{A} / \mathrm{C}$ & $0-10 \mathrm{~cm}$ & 1 \\
\hline & & & & $\mathrm{B} / \mathrm{C}$ & $11-70 \mathrm{~cm}$ & 4 \\
\hline \multirow{2}{*}{ LB } & \multirow{2}{*}{ Leão Beach } & \multirow{2}{*}{$0 \mathrm{~m}$} & \multirow{2}{*}{ Ne-basalt + Trachyte } & $\mathrm{A} / \mathrm{C}$ & $0-10 \mathrm{~cm}$ & 1 \\
\hline & & & & $\mathrm{B} / \mathrm{C}$ & $11-40 \mathrm{~cm}$ & 3 \\
\hline
\end{tabular}

the A organic-rich horizon $(0-30 \mathrm{~cm})$ through the $\mathrm{A} / \mathrm{B}-$ horizon $(31-190 \mathrm{~cm})$ to the $\mathrm{B}$ horizon $(191-290 \mathrm{~cm})$. The remaining four soil profiles were sampled down to the $\mathrm{B}$ or $\mathrm{B} / \mathrm{C}$ horizons using an auger. Table I summarizes the main characteristics of the sampled soil profiles.

\section{Analytical Procedures}

Bulk mineralogical composition was determined by X-ray powder diffraction (XRD) in normal, ethylene glycol saturated and heated $\left(\right.$ at $\left.500^{\circ} \mathrm{C}\right)$ oriented samples. 
X-ray analyses were performed at the Institute of Geosciences, University of São Paulo, on a Siemens automated powder diffractometer equipped with a graphite monochromator. All slides were scanned over $2 \theta$ range $3-60^{\circ}$ with a step size of $0.05^{\circ}$ using a $\mathrm{CuK} \alpha$ radiation at $40 \mathrm{kV}$ and $40 \mathrm{~mA}$.

For chemical analyses, samples were dried overnight at $40^{\circ} \mathrm{C}$ and pulverized to about $<0.062 \mathrm{~mm}$ in a tungsten carbide mill. Analytical data for the major elements ( $\mathrm{Si}, \mathrm{Al}, \mathrm{Fe}, \mathrm{Mn}, \mathrm{Mg}, \mathrm{Ca}, \mathrm{Na}, \mathrm{K}, \mathrm{Ti}$ and $\mathrm{P}$ ) and selected trace elements $(\mathrm{Ba}, \mathrm{Cu}, \mathrm{Ga}, \mathrm{Nb}, \mathrm{Ni}, \mathrm{Sr}, \mathrm{V}$, $\mathrm{Y}, \mathrm{Zn}, \mathrm{Zr}$ ) were obtained by conventional wave-length dispersive X-ray fluorescence (XRF). XRF analyses of standard reference material showed accuracy and precision to be better than 5\% RDS (Mori et al. 1999). The loss on ignition (LOI) was determined at the interval 100 to $1000^{\circ} \mathrm{C}$ for 60 minutes. $\mathrm{XRD}$ and $\mathrm{XRF}$ procedures were carried out at the Institute of Geosciences, University of São Paulo. Additional trace (Co, Cr, Hf, Sc, Ta, Th, U) concentrations were determined by Instrumental Neutron Activation Analysis (INAA). Sample reference materials and synthetic standards were irradiated for 16 hours in a thermal neutron flux of $10^{12} \mathrm{n} \mathrm{cm}^{-1} \mathrm{~s}^{-1}$ in the IEA-R1 nuclear reactor at IPEN - Institute of Nuclear and Energetic Research (São Paulo). Mercury was measured by cold vapor-atomic absorption spectrometry (CV-AAS) technique in a flow injection mercury system (FIMS) after total digestion by a mixture of $\mathrm{HNO}_{3}, \mathrm{H}_{2} \mathrm{SO}_{4}$ and $\mathrm{H}_{2} \mathrm{O}_{2}$ at the same Institute. All $\mathrm{Hg}$ determinations were performed in duplicate, and the detection limit was $2 \mathrm{ppb}$. Results were consistently within $10 \%$ of each other. The INAA methodology validation was performed by measuring the reference materials NIST SRM 2704, IAEA and IWG-GIT, and the AAS methodology, NIST SRM 2704, NIST SRM 1646, and BCR CRM 280. The lower limit detection for the elements determined by XRF and INAA were well below the lowest measured concentrations in all samples.

\section{RESULTS AND DISCUSSION}

\section{SoIl Mineralogy}

The mineralogical composition of the analysed soils is summarized in Table II. A general characteristic is the absence of quartz and the presence of significant amounts of non-crystalline phases. The dominant components in all soils are clay minerals: kaolinite in soils derived from the nepheline basalts of the Quixaba Formation (MQ, SB and MP sites), and the 17A swelling clay (smectite) in soils derived from the more acid lithologies of the Remédios Formation (AB and LB sites). Goethite and hematite are present in small amounts in all soils. Some of the primary constituents of the volcanic rocks - magnetite, ilmenite, pseudobrookite, zeolite and pyroxene - can also be found in minor amounts in most soil samples.

Major And TRace Element Concentrations In SoIls In Table III, major element concentrations are listed for all of the 43 samples analysed. Also shown are TOC (total organic carbon), $\mathrm{SiO}_{2} / \mathrm{Al}_{2} \mathrm{O}_{3}$ ratios and CIA (Chemical Index of Alteration). CIA was calculated from the chemical analysis of the soils by taking the molecular proportions of the oxides (Nesbitt and Young 1982): $\mathrm{CIA}=\left[\mathrm{Al}_{2} \mathrm{O}_{3} /\left(\mathrm{Al}_{2} \mathrm{O}_{3}+\mathrm{CaO}+\mathrm{Na}_{2} \mathrm{O}+\mathrm{K}_{2} \mathrm{O}\right)\right]$.

The chemical composition of FN soils is dominated by $\mathrm{SiO}_{2}, \mathrm{Al}_{2} \mathrm{O}_{3}, \mathrm{Fe}_{2} \mathrm{O}_{3}$ and $\mathrm{TiO}_{2} . \mathrm{MgO}$ is present in significant amounts only in the less weathered horizons of the soil profiles. $\mathrm{Na}_{2} \mathrm{O}, \mathrm{K}_{2} \mathrm{O}$ and $\mathrm{CaO}$ contents are remarkably low throughout the profiles. The organic matter (TOC) content of soils decreases with depth, varying between $2.7-0.9 \%$ and $0.8-0.1 \%$, respectively, for surface and deep horizons. CIA reaches high values within the group of soils developed at higher altitudes (from 0.95 to 0.99 in the MQ site, from 0.62 to 0.93 in the SB site, and from 0.82 to 0.94 in the MQ site), pointing to a high degree of pedological evolution. On the other hand, in soils developed at the sea level, CIA values are lower, ranging from 0.71 to 0.76 in the $\mathrm{AB}$ site, and from 0.66 to 0.67 in the LB site.

Table IV displays the overall results for the trace element concentrations. The distribution of the heavy metals with depth (Fig. 2) varies according to the element and to the different soil profiles. In MQ, SB and MP sites, the concentrations of $\mathrm{Zn}$ and Co decrease with depth. $\mathrm{Hg}, \mathrm{Cr}$ and $\mathrm{Ni}$ concentrations display a similar pattern in the MQ site, but in SB and MP sites Cr and $\mathrm{Ni}$ do not show a systematic pattern with depth. In the $\mathrm{AB}$ site, the heavy metal contents increase slightly with depth, and in the LB site their concentrations slightly 
TABLE II

Mineralogical composition of the Fernando de Noronha soils.

Kaol $=$ kaolinite, Smec $=$ smectite, Goe $=$ goethite, Hem $=$ hematite, Anat $=$ anatase, Non-cryst $=$ non-crystalline phases.

$\mathrm{XXX}=$ very abundant, $\mathrm{XX}=$ abundant, $X=$ present, $(X)=$ trace.

\begin{tabular}{c|c|c|c|c|c|c}
\hline Profile & Horizon & Kaol & Smec & Goe+Hem & Anat & Non-cryst \\
\hline \multirow{4}{*}{ MQ } & $\mathrm{A}$ & $\mathrm{XXX}$ & & $\mathrm{X}$ & $\mathrm{X}$ & $(\mathrm{X})$ \\
\hline & $\mathrm{A} / \mathrm{B}$ & $\mathrm{XXX}$ & & $\mathrm{X}$ & $\mathrm{X}$ & $(\mathrm{X})$ \\
\hline & $\mathrm{B}$ & $\mathrm{XX}$ & $(\mathrm{X})$ & $\mathrm{X}$ & & $(\mathrm{X})$ \\
\hline \multirow{4}{*}{$\mathrm{SB}$} & $\mathrm{A}$ & $\mathrm{XXX}$ & & $\mathrm{X}$ & & $\mathrm{X}$ \\
\cline { 2 - 7 } & $\mathrm{B}$ & $\mathrm{XXX}$ & & $\mathrm{X}$ & & $\mathrm{X}$ \\
\hline & $\mathrm{B} / \mathrm{C}$ & $\mathrm{XXX}$ & & $\mathrm{X}$ & & $(\mathrm{X})$ \\
\hline \multirow{3}{*}{$\mathrm{MP}$} & $\mathrm{A}$ & $\mathrm{XX}$ & & $\mathrm{X}$ & & $\mathrm{XX}$ \\
\hline & $\mathrm{B}$ & $\mathrm{XX}$ & & $\mathrm{X}$ & & $\mathrm{XX}$ \\
\hline \multirow{3}{*}{$\mathrm{AB}$} & $\mathrm{A} / \mathrm{C}$ & & $\mathrm{XXX}$ & $\mathrm{X}$ & & $\mathrm{X}$ \\
\hline & $\mathrm{B} / \mathrm{C}$ & & $\mathrm{XXX}$ & $\mathrm{X}$ & $\mathrm{X}$ & $\mathrm{X}$ \\
\hline \multirow{2}{*}{$\mathrm{LB}$} & $\mathrm{A} / \mathrm{C}$ & & $\mathrm{XX}$ & $\mathrm{X}$ & & $\mathrm{X}$ \\
\hline & $\mathrm{B} / \mathrm{C}$ & & $\mathrm{XX}$ & $\mathrm{X}$ & $\mathrm{X}$ & $\mathrm{XX}$ \\
\hline
\end{tabular}

TABLE III

Soil composition: major oxides $(\%)$, TOC $=$ total organic carbon $(\%)$, CIA $=$ chemical index of alteration (Nesbitt and Young 1982), sd = standard deviation.

\begin{tabular}{c|c|c|c|c|c|c|c|c|c|c}
\hline & \multicolumn{2}{|c|}{$\mathrm{MQ}(\mathrm{n}=16)$} & \multicolumn{2}{c|}{$\mathrm{SB}(\mathrm{n}=10)$} & \multicolumn{2}{c}{$\mathrm{MP}(\mathrm{n}=8)$} & \multicolumn{2}{c}{$\mathrm{AB}(\mathrm{n}=5)$} & \multicolumn{2}{c}{$\mathrm{LB}(\mathrm{n}=4)$} \\
\cline { 2 - 12 } & mean & sd & mean & sd & mean & sd & mean & sd & mean & sd \\
\hline $\mathrm{SiO}_{2}$ & 29.05 & 4.16 & 28.97 & 1.65 & 24.20 & 1.97 & 40.21 & 1.52 & 34.77 & 0.52 \\
\hline $\mathrm{Al}_{2} \mathrm{O}_{3}$ & 23.53 & 1.29 & 22.44 & 1.56 & 20.65 & 1.43 & 18.65 & 0.74 & 15.12 & 0.36 \\
\hline $\mathrm{MnO}$ & 0.23 & 0.24 & 0.25 & 0.06 & 0.52 & 0.10 & 0.17 & 0.05 & 0.30 & 0.02 \\
\hline $\mathrm{MgO}$ & 1.04 & 0.29 & 2.85 & 1.19 & 1.93 & 0.44 & 2.42 & 0.06 & 3.56 & 0.08 \\
\hline $\mathrm{CaO}$ & 0.15 & 0.12 & 1.24 & 1.43 & 0.97 & 0.49 & 1.60 & 0.27 & 2.86 & 0.10 \\
\hline $\mathrm{Na}_{2} \mathrm{O}$ & 0.16 & 0.13 & 0.85 & 0.34 & 0.33 & 0.20 & 1.08 & 0.06 & 0.72 & 0.05 \\
\hline $\mathrm{K}_{2} \mathrm{O}$ & 0.04 & 0.05 & 0.16 & 0.07 & 0.25 & 0.04 & 1.58 & 0.16 & 0.90 & 0.01 \\
\hline $\mathrm{TiO}_{2}$ & 5.99 & 0.31 & 5.67 & 0.35 & 5.41 & 0.17 & 5.02 & 0.43 & 6.14 & 0.14 \\
\hline $\mathrm{P}_{2} \mathrm{O}_{5}$ & 0.68 & 0.31 & 1.91 & 0.20 & 1.48 & 0.14 & 2.01 & 0.71 & 1.30 & 0.01 \\
\hline $\mathrm{Fe}{ }_{2} \mathrm{O}_{3}$ & 26.91 & 1.68 & 24.99 & 1.56 & 30.84 & 4.18 & 15.81 & 1.67 & 25.12 & 0.50 \\
\hline $\mathrm{LOI}^{2}$ & 11.95 & 2.11 & 10.49 & 1.37 & 13.19 & 1.79 & 10.51 & 0.35 & 8.06 & 0.52 \\
\hline $\mathrm{Si} / \mathrm{Al}$ & 1.06 & 0.21 & 1.11 & 0.15 & 1.00 & 0.06 & 1.83 & 0.06 & 1.95 & 0.02 \\
\hline $\mathrm{TOC}$ & 0.54 & 0.68 & 0.35 & 0.31 & 1.20 & 0.79 & 1.14 & 0.30 & 0.66 & 0.18 \\
\hline $\mathrm{CIA}$ & 0.98 & 0.01 & 0.86 & 0.10 & 0.89 & 0.04 & 0.74 & 0.02 & 0.67 & 0.00 \\
\hline
\end{tabular}

decrease, or remain rather stable, with depth. The concentrations of $\mathrm{Cu}$ present no systematic behavior with depth.

For almost all soil samples, the heavy metal contents exceed the world range for non-polluted soils (Kabata-
Pendias and Pendias 1992), the Chinese environmental quality standard for soils (Chen et al. 1999), and the São Paulo State Environmental Agency (CETESB) standard for soils (Casarini et al. 2001) (Table V). However, this finding must be interpreted taking into account that 
TABLE IV

Soil composition: trace elements (ppm), except Hg (ppb), nd $=$ not determined, $\mathbf{s d}=$ standard deviation.

\begin{tabular}{c|c|c|c|c|c|c|c|c|c|c}
\hline \multirow{2}{*}{} & \multicolumn{2}{|c|}{ MQ $(\mathrm{n}=16)$} & \multicolumn{2}{c|}{$\mathrm{SB}(\mathrm{n}=10)$} & \multicolumn{2}{c|}{$\mathrm{MP}(\mathrm{n}=8)$} & \multicolumn{2}{c|}{$\mathrm{AB}(\mathrm{n}=5)$} & \multicolumn{2}{c}{ LB $(\mathrm{n}=4)$} \\
\cline { 2 - 13 } & mean & $\mathrm{sd}$ & mean & sd & mean & sd & mean & sd & mean & sd \\
\hline $\mathrm{Ba}$ & 471 & 140 & 503 & 160 & 755 & 99 & 771 & 87 & 833 & 11 \\
\hline $\mathrm{Ga}$ & 41 & 3 & 38 & 3 & 37 & 1 & 32 & 0 & 29 & 1 \\
\hline $\mathrm{Hf}$ & 11 & 1 & 13 & 1 & 10 & 1 & 13 & 1 & 9 & 1 \\
\hline $\mathrm{Nb}$ & 167 & 9 & 125 & 8 & 148 & 4 & 160 & 11 & 170 & 4 \\
\hline $\mathrm{Sr}$ & 343 & 57 & 326 & 205 & 364 & 62 & 513 & 33 & 528 & 7 \\
\hline $\mathrm{Sc}$ & 44.6 & 2.3 & 38.7 & 2.1 & 40.8 & 1.7 & 23.8 & 1.8 & 31.2 & 1.4 \\
\hline $\mathrm{Ta}$ & 8.9 & 0.7 & 8.5 & 0.7 & 8.2 & 0.5 & 9.3 & 0.8 & 8.9 & 0.7 \\
\hline $\mathrm{Th}$ & 24.8 & 1.3 & 10.4 & 0.7 & 23.3 & 1.6 & 18.4 & 1.2 & 18.0 & 0.8 \\
\hline $\mathrm{U}$ & 3.4 & 0.9 & 3.3 & 0.4 & 3.7 & 0.5 & 8.2 & 1.3 & 3.1 & 0.3 \\
\hline $\mathrm{V}$ & 299 & 80 & 469 & 48 & 591 & 57 & 370 & 29 & 311 & 15 \\
\hline $\mathrm{Y}$ & 38 & 24 & 44 & 9 & 47 & 3 & 30 & 1 & 45 & 1 \\
\hline $\mathrm{Zr}$ & 478 & 26 & 545 & 35 & 416 & 16 & 632 & 32 & 410 & 1 \\
\hline $\mathrm{Co}$ & 72 & 81 & 92 & 26 & 155 & 21 & 61 & 12 & 98 & 10 \\
\hline $\mathrm{Cr}$ & 705 & 111 & 548 & 29 & 1081 & 182 & 397 & 50 & 590 & 40 \\
\hline $\mathrm{Cu}$ & 60 & 9 & 67 & 15 & 70 & 4 & 39 & 5 & 96 & 1 \\
\hline $\mathrm{Hg}$ & 30.8 & 43.3 & $\mathrm{nd}$ & $\mathrm{nd}$ & $\mathrm{nd}$ & $\mathrm{nd}$ & $\mathrm{nd}$ & $\mathrm{nd}$ & $\mathrm{nd}$ & $\mathrm{nd}$ \\
\hline $\mathrm{Ni}$ & 222 & 75 & 600 & 53 & 344 & 21 & 130 & 10 & 221 & 2 \\
\hline $\mathrm{Zn}$ & 157 & 67 & 180 & 28 & 219 & 28 & 166 & 24 & 304 & 3 \\
\hline
\end{tabular}

the Fernando de Noronha soils were developed from already geochemically anomalous rocks when compared to the composition of the average upper continental crust (Wedepohl 1995) (Table V). Furthermore, pedogenesis on volcanic rocks is characterized by the neoformation of non-crystalline phases intimately associated with organic matter, known to show a strong retention of heavy metals (Hernandez et al. 2003). In the FN soils, such phases are abundant and can also account for the high concentrations of $\mathrm{Cr}, \mathrm{Co}, \mathrm{Ni}, \mathrm{Zn}$ and $\mathrm{Cu}$ observed. On the other hand, compared with the products of weathering alteration of rocks of similar geochemical composition, such as the nepheline basalts from the French Massif Central (Soubrand-Colin et al. 2005), the FN soils are in the same range of heavy metal concentrations (Table V).

\section{PARENT ROCK INHERITANCE}

Soils developed from nepheline basalts (MQ, SB, and MP sites) present higher $\mathrm{Fe}_{2} \mathrm{O}_{3}$ contents and lower $\mathrm{SiO}_{2}$ and $\mathrm{K}_{2} \mathrm{O}$ contents than soils developed from more acid lithologies ( $\mathrm{AB}$ and $\mathrm{LB}$ sites). In the MQ, SB and MP soils, $\mathrm{SiO} 2 / \mathrm{Al}_{2} \mathrm{O}_{3}$ ratios are lower compared with the ratios in the $\mathrm{AB}$ and $\mathrm{LB}$ soils, which reflects the presence of kaolinite in the former group of soils and smectite in the latter.

In order to investigate whether it was possible to distinguish different soils on the basis of similarities of their trace element composition, a cluster analysis was carried out. The dendrogram in Figure 3 shows two groups of soils based on the magmatic affinity of the parent rock: soils developed from the more unsaturated ultramafic rocks of the Quixaba Formation from those developed from the less unsaturated rocks of the Remédios Formation. Furthermore, within the latter, two subgroups corresponding to different parent rocks could be detected: one formed by SB soils and another by $\mathrm{AB}$ soils. Overall, the results of the cluster analysis confirm that the chemical composition of soils is mainly determined by the parent material. 

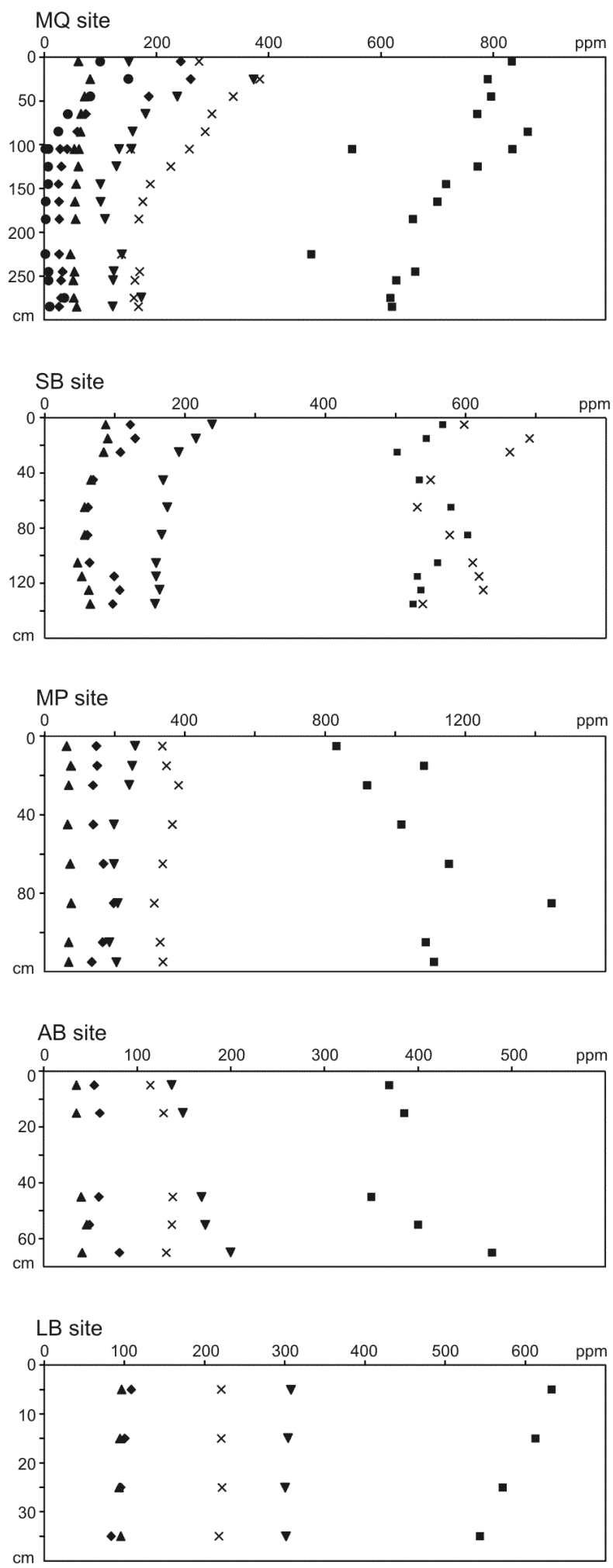

Fig. 2 - Total heavy metal concentrations (ppm) in soil profiles: $\mathrm{Cr}=$ solid squares; $\mathrm{Zn}=$ solid inverted triangles; $\mathrm{Ni}=\mathrm{crosses}$; $\mathrm{Cu}=$ solid triangles; $\mathrm{Co}=$ solid diamonds; Soil profiles: $\mathrm{MQ}=$ Morro do Quixaba; $\mathrm{SB}=$ Sancho Bay; MP = Mata Ponta Oeste; $\mathrm{AB}=$ Ponta de Atalaia; $\mathrm{LB}=$ Leão Beach. 
TABLE V

Heavy metal concentrations (ppm) in: FN soils (this work), Non-polluted soils (Kabata-Pendias and Pendias 1992), Chinese environmental quality standard for soils (Chen et al. 1999), Fernando de Noronha rocks: Ne-basalts, Essexite and Trachyte (Gunn and Watkins 1976, Weaver 1990, Ulbrich et al. 1994, Lopes and Ulbrich 2006), UCC - upper continental crust (Wedepohl 1995), FMC - ne-basalts from the French Massif Central (Soubrand-Colin et al. 2005).

\begin{tabular}{l|c|c|c|c|c|c}
\hline & $\mathrm{Co}$ & $\mathrm{Cu}$ & $\mathrm{Cr}$ & $\mathrm{Ni}$ & $\mathrm{Zn}$ & $\mathrm{Hg} \mathrm{ppb}$ \\
\hline FN soils & $26-261$ & $35-97$ & $350-1446$ & $114-691$ & $101-374$ & $2-150$ \\
\hline Non poll soils & $0.1-20$ & $6-60$ & $5-120$ & $1-200$ & $17-125$ & $\mathrm{nd}$ \\
\hline Chinese stand & $\mathrm{nd}$ & 35 & 90 & 40 & 100 & 150 \\
\hline Ne-basalts & $56-65$ & $22-70$ & $252-686$ & $70-451$ & $103-128$ & $\mathrm{nd}$ \\
\hline Essexite & $20-21$ & $19-20$ & $62-110$ & $55-83$ & $99-100$ & $\mathrm{nd}$ \\
\hline Trachyte & $2-10$ & $34-36$ & $5-11$ & $4-16$ & $77-123$ & $\mathrm{nd}$ \\
\hline UCC & 12 & 14 & 35 & 19 & 52 & 56 \\
\hline FMC & $\mathrm{nd}$ & $33-71$ & $293-686$ & $168-291$ & $110-168$ & $\mathrm{nd}$ \\
\hline
\end{tabular}

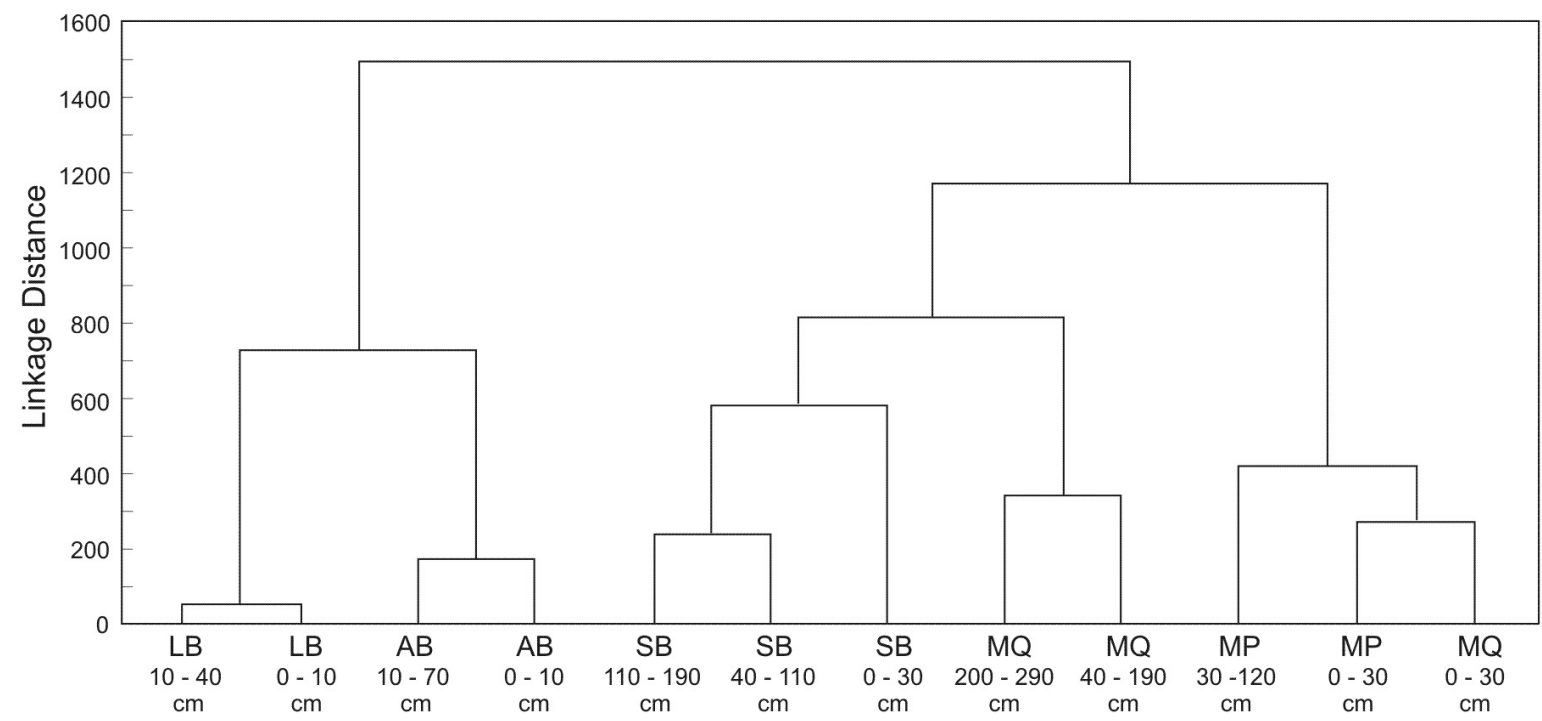

Fig. 3 - Dendrogram from cluster analysis based on trace element composition of soils. Ward's method, euclidean distances. $\mathrm{MQ}=$ Morro do Quixaba; SB = Sancho Bay; MP = Mata Ponta Oeste; AB = Ponta de Atalaia; LB = Leão Beach.

Soils developed from more mafic rocks, corresponding to MQ, SB and MP sites, present the highest $\mathrm{Co}, \mathrm{Ni}$ and $\mathrm{Cr}$ contents, while the lowest concentrations are found in soil samples developed from the less mafic rocks (essexite) corresponding to the $\mathrm{AB}$ site. On the other hand, the $\mathrm{AB}$ soils present the highest contents of $\mathrm{Ba}, \mathrm{Sr}, \mathrm{Zr}$, Hf and U. Soils developed under the influence of both a nepheline basalt and an alkaline trachyte (LB site) contain a characteristic heavy metal signature: $\mathrm{Cu}$ and $\mathrm{Zn}$ concentrations are the most elevated of all soils analysed, while $\mathrm{Cr}$, $\mathrm{Co}$ and $\mathrm{Ni}$ are in the range of the MQ soils.

\section{Influence of Pedogenesis on Heavy Mineral} Distribution IN SOIL ProfiLes

Relationships between major elements and heavy metals

Total organic carbon, aluminum, iron and manganese are generally considered important factors in evaluating heavy metal content in soils (Baize and Sterckeman 
TABLE VI

Pearson correlation matrix for heavy metals, $\mathrm{Mn}, \mathrm{Fe}$ and TOC in all soil samples ( $n=43$; *correlation is significant at $\mathbf{P}<0.001 ; * * \mathbf{P}<0.005)$.

\begin{tabular}{c|c|c|c|c|c|c|c|c|c}
\hline & TOC & $\mathrm{Al}$ & $\mathrm{Fe}$ & $\mathrm{Mn}$ & $\mathrm{Co}$ & $\mathrm{Cr}$ & $\mathrm{Cu}$ & $\mathrm{Ni}$ & $\mathrm{Zn}$ \\
\hline $\mathrm{TOC}$ & 1.00 & & & & & & & & \\
$\mathrm{Al}$ & -0.10 & 1.00 & & & & & & & \\
$\mathrm{Fe}$ & -0.15 & 0.26 & 1.00 & & & & & & \\
$\mathrm{Mn}$ & $0.59^{*}$ & -0.07 & 0.41 & 1.00 & & & & & \\
$\mathrm{Co}$ & $0.60^{*}$ & -0.05 & 0.32 & $0.98^{*}$ & 1.00 & & & & \\
$\mathrm{Cr}$ & 0.20 & 0.12 & $0.85^{*}$ & $0.65^{*}$ & $0.55^{*}$ & 1.00 & & & \\
$\mathrm{Cu}$ & 0.09 & -0.25 & $0.44^{* *}$ & $0.47^{* *}$ & $0.49^{*}$ & 0.32 & 1.00 & & \\
$\mathrm{Ni}$ & -0.10 & 0.29 & 0.19 & 0.24 & 0.34 & 0.03 & 0.33 & 1.00 & \\
$\mathrm{Zn}$ & $0.45^{* *}$ & $-0.44^{* *}$ & 0.08 & $0.60^{*}$ & $0.63^{*}$ & 0.17 & $0.74^{*}$ & 0.16 & 1.00 \\
\hline
\end{tabular}

2001). The correlations between these variables for the Fernando de Noronha soils are presented in the form of a Pearson correlation coefficient matrix in Table VI.

A highly significant correlation was observed between $\mathrm{Mn}$ and $\mathrm{Co}\left(\mathrm{r}^{2}=0.98, \mathrm{n}=43, \mathrm{P}<0.001\right)$ (Fig. $4 a)$, which is probably related to the preferential association of this metal with the manganese oxides. Mn and $\mathrm{Zn}$ are also significantly correlated (Fig. $4 \mathrm{~b}$ ) considering all samples $\left(\mathrm{r}^{2}=0.60, \mathrm{n}=43, \mathrm{P}<0.001\right)$; this relationship becomes weaker with $\mathrm{Cu}\left(\mathrm{r}^{2}=0.47, \mathrm{n}\right.$ $=43, \mathrm{P}<0.005)($ Fig. $4 \mathrm{c}$ ) and Ni (Table VI). For the SB soils only, the correlations $\mathrm{Mn}-\mathrm{Zn}$ and $\mathrm{Mn}-\mathrm{Cu}$ are much stronger $\left(\mathrm{Mn}-\mathrm{Zn} \mathrm{r}{ }^{2}=0.84 ; \mathrm{Mn}-\mathrm{Cu} \mathrm{r}^{2}=0.90, \mathrm{n}\right.$ $=10, \mathrm{P}<0.001)($ Fig. $4 \mathrm{~b}, \mathrm{c})$.

A significant relationship was found between TOC and $\mathrm{Co}\left(\mathrm{r}^{2}=0.60, \mathrm{n}=43, \mathrm{P}<0.001\right)$; this relationship is even stronger in the MQ site $\left(\mathrm{r}^{2}=0.90, \mathrm{n}=\right.$ 16, $\mathrm{P}<0.001$ ) (Fig. 4d). Between $\mathrm{Zn}$ and TOC the correlation is weaker $\left(\mathrm{r}^{2}=0.45, \mathrm{n}=43, \mathrm{P}<0.01\right)$, but considering only the SB soils, it is highly significant $\left(\mathrm{r}^{2}=0.98, \mathrm{n}=10, \mathrm{P}<0.001\right) . \mathrm{Cr}, \mathrm{Cu}$ and $\mathrm{Ni}$ contents do not correlate significantly with TOC (Table VI). Ni shows no significant correlations with other elements when all of the soil samples are considered. However, Ni correlates significantly with TOC (Fig. 4e), as well as Mn (Fig. 4f) in the MQ soil profile (TOCNi $\left.\mathrm{r}^{2}=0.64 ; \mathrm{Mn}-\mathrm{Ni} \mathrm{r}^{2}=0.78 ; \mathrm{n}=16, \mathrm{P}<0.005\right)$ and with $\mathrm{Mn}$ in the SB soil profile (Mn-Ni $\mathrm{r}^{2}=0.72, \mathrm{n}=$ $10, \mathrm{P}<0.02$ ) (Fig. 4f).
Fe is significantly correlated with $\mathrm{Cr}$ considering all soil samples $\left(\mathrm{r}^{2}=0.85, \mathrm{n}=43, \mathrm{P}<0.0001\right)$ (Fig. $4 \mathrm{~g}$ ); the same was found for samples of each soil profile, which indicates a strong affinity of $\mathrm{Cr}$ for the iron oxides. The relationship between $\mathrm{Fe}$ and $\mathrm{Cu}$ is also positive, but less significant $\left(r^{2}=0.44, n=43, P<0.005\right)$ (Fig. 4h). Fe did not correlate significantly with $\mathrm{Co}$, $\mathrm{Ni}$ and $\mathrm{Zn}$.

Considering only the MQ soils, $\mathrm{Hg}$ was strongly correlated with TOC and Mn (TOC-Hg r ${ }^{2}=0.87, \mathrm{Mn}-$ $\left.\mathrm{Hg} \mathrm{r}^{2}=0.97, \mathrm{n}=16 \mathrm{P}<0.001\right)$. Fe did not correlate significantly with $\mathrm{Hg}\left(\mathrm{Hg}-\mathrm{Fe} \mathrm{r}^{2}=-0.10, \mathrm{n}=16\right)$.

No clear relationship between $\mathrm{Al}$ and the heavy metals was detected in this study, which suggests that the clay content does not control the amount of $\mathrm{Cr}, \mathrm{Cu}$, $\mathrm{Zn}, \mathrm{Co}$, and Ni of soils. On the other hand, the manganese oxides and/or the organic matter seem to be important controlling factors in the fixation of $\mathrm{Zn}, \mathrm{Co}, \mathrm{Ni}$, $\mathrm{Cu}$ and $\mathrm{Hg}$ in the studied soils. Iron oxides and hydrous oxides play a major role only in the retention of $\mathrm{Cr}$.

\section{Enrichment factors}

Enrichment factors (EF) were calculated in order to assess the enrichment or depletion of a trace element in a given soil horizon. EF considers the abundance of the element of interest relative to the abundance of a conservative, lithogenic element with no significant anthropogenic source. This ratio is then normalized to the corresponding ratio in the sample at the lowest soil 

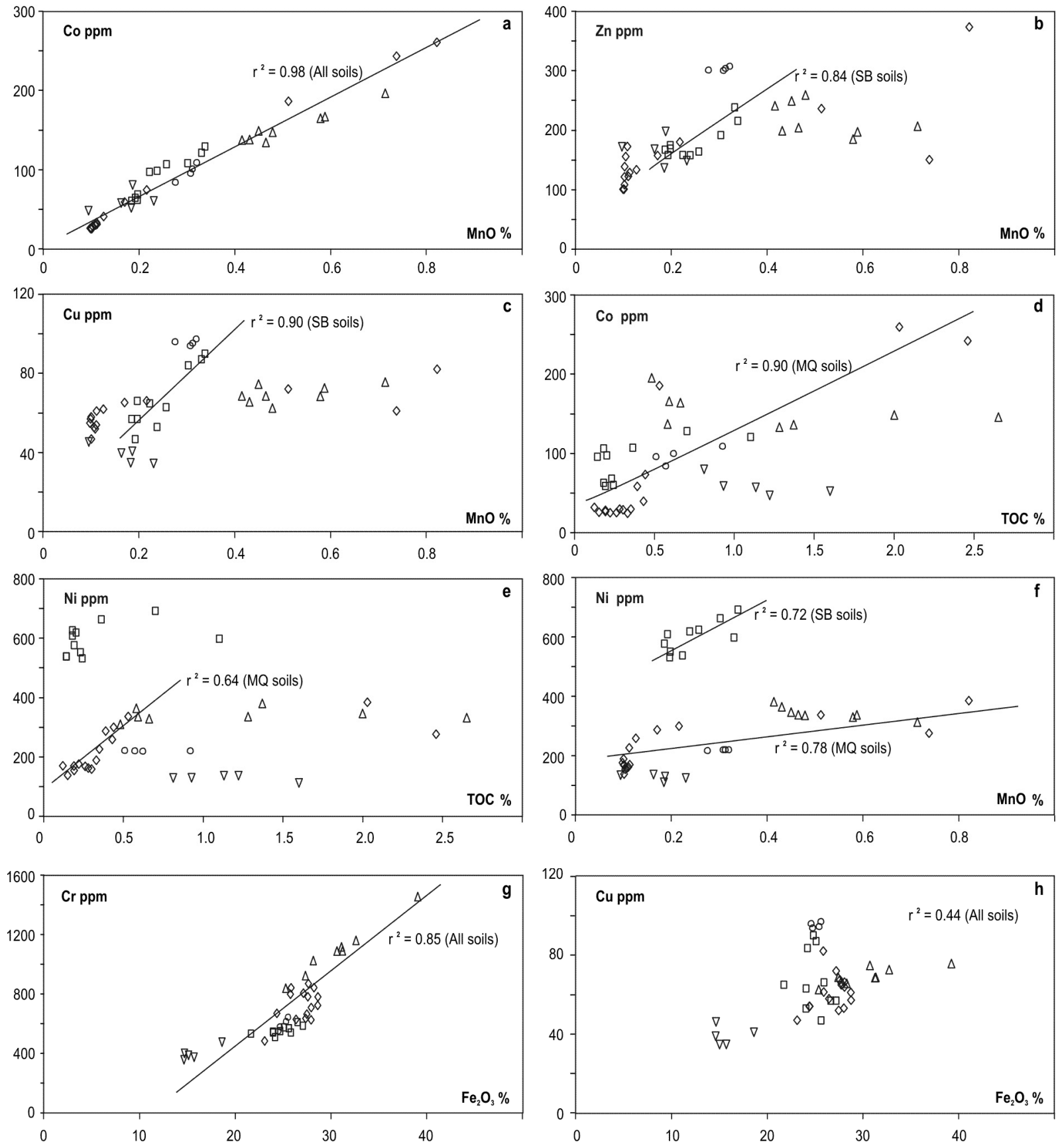

Fig. 4 - Relationships between the heavy metal contents and $\mathrm{MnO}$, TOC and $\mathrm{Fe}_{2} \mathrm{O}_{3}$ in soil samples. Samples from MQ site: open diamonds; SB site: open squares; MP site: open triangles; AB site: open inverted triangles; LB site: open circles. 
TABLE VII

EF-Enrichment Factors calculated against the deepest horizon values in the studied soil profiles.

\begin{tabular}{c|c|c|c|c|c|c|c}
\hline & $\mathrm{cm}$ & $\mathrm{Cr}$ & $\mathrm{Co}$ & $\mathrm{Ni}$ & $\mathrm{Cu}$ & $\mathrm{Zn}$ & $\mathrm{Hg}$ \\
\hline \multirow{4}{*}{ MQ } & $0-30$ & 1.18 & 8.50 & 1.76 & 1.11 & 1.93 & 11.21 \\
\cline { 2 - 8 } & $31-190$ & 1.14 & 2.04 & 1.33 & 0.98 & 1.08 & 2.20 \\
\cline { 2 - 8 } & $191-290$ & 0.88 & 1.01 & 0.87 & 0.85 & 1.06 & 1.02 \\
\hline \multirow{4}{*}{ SB } & $0-30$ & 0.89 & 1.07 & 1.04 & 1.16 & 1.18 & $\mathrm{nd}$ \\
\cline { 2 - 8 } & $31-110$ & 0.92 & 0.56 & 0.89 & 0.74 & 0.90 & $\mathrm{nd}$ \\
\cline { 2 - 8 } & $111-140$ & 0.94 & 0.97 & 1.03 & 0.87 & 0.95 & $\mathrm{nd}$ \\
\hline \multirow{3}{*}{ MP } & $0-30$ & 0.77 & 0.97 & 0.95 & 0.90 & 1.11 & $\mathrm{nd}$ \\
\cline { 2 - 8 } & $31-120$ & 0.99 & 1.13 & 0.94 & 0.97 & 0.92 & $\mathrm{nd}$ \\
\hline \multirow{2}{*}{ LB } & $0-10$ & 1.05 & 1.17 & 0.92 & 0.91 & 0.92 & $\mathrm{nd}$ \\
\cline { 2 - 8 } & $11-40$ & 1.06 & 1.11 & 1.01 & 0.99 & 1.00 & $\mathrm{nd}$ \\
\hline \multirow{2}{*}{ AB } & $0-10$ & 0.91 & 0.78 & 1.02 & 1.00 & 0.81 & $\mathrm{nd}$ \\
\cline { 2 - 8 } & $11-70$ & 0.91 & 0.82 & 1.10 & 1.06 & 0.93 & $\mathrm{nd}$ \\
\hline
\end{tabular}

depth (Blaser et al. 2000). Here we used Sc as the lithogenic element. $\mathrm{EF}$ for $\mathrm{Ba}, \mathrm{Sr}$, Th, Ta, $\mathrm{Hf}, \mathrm{Zr}, \mathrm{Nb}, \mathrm{Cr}, \mathrm{Co}$, $\mathrm{Ni}, \mathrm{Cu}, \mathrm{Zn}$, and $\mathrm{Hg}$ in each horizon of the soil profiles were calculated:

$$
\mathrm{EF}=\left[(\mathrm{Me} / \mathrm{Sc})_{\text {soil }} /(\mathrm{Me} / \mathrm{Sc})_{\text {lowest soil sample }}\right],
$$

where $\mathrm{Me}=$ total metal concentration, and $\mathrm{Sc}=$ total Sc concentration.

Results for the conservative elements $\mathrm{Ba}, \mathrm{Sr}, \mathrm{Th}, \mathrm{Ta}$, $\mathrm{Hf}, \mathrm{Zr}$ were between 0.5 and 2.0 (not shown), which is considered in the range of natural variability (Hernandez et al. 2003).

EFs for the heavy metals are displayed in Table VII. $\mathrm{Cr}, \mathrm{Ni}$ and $\mathrm{Zn}$ behave as conservative elements $(0.7<$ $\mathrm{EF}<1.9$ ). The only anomalous $\mathrm{EF}$ values are found in the MQ site for Co and $\mathrm{Hg}$, particularly in the $0-30 \mathrm{~cm}$ horizon ( 8.50 and 11.21 , respectively). In the $31-190 \mathrm{~cm}$ horizon, $\mathrm{EF}$ values for $\mathrm{Co}$ and $\mathrm{Hg}$ just slightly exceeded the upper limit considered to be in the range of natural variability (2.04 and 2.20, respectively).

The very high $\mathrm{EF}$ values for $\mathrm{Hg}$ in the uppermost soil horizon of the MQ profile are probably related to atmospheric deposition from anthropogenic sources. There is consistent evidence that long-range atmospheric transport and deposition of $\mathrm{Hg}$ emitted mainly from mining and industrial activities are responsible for $\mathrm{Hg}$ pollution in surface soils even in pristine areas (Fitz- gerald et al. 1998, Hylander and Meili 2003, Lindberg et al. 2007). Furthermore, in the Fernando de Noronha island, a signal of atmospherically transported humanrelated $\mathrm{Hg}$ emissions was detected in the sediments of a small lake (Oliveira et al. 2009). On the other hand, the tendency to form quite stable complexes with humic compounds (Schlüter and Gaeth 1997, Valle et al. 2005) could have also contributed to the accumulation of $\mathrm{Hg}$ in the upper horizons of the MQ soil profile.

$\mathrm{Co}$, unlike $\mathrm{Hg}$, is not a volatile element and could hardly be atmospherically transported in the absence of local pollution sources. Moreover, Co presents a very high geochemical affinity for $\mathrm{Mn}$, being incorporated in the octahedral layers of the secondary Mn oxides formed during weathering (Manceau et al. 1987). Thus, in the MQ soils, high concentrations of $\mathrm{Co}$ in the $0-30 \mathrm{~cm}$ horizon is probably related to the manganese oxides that are also very concentrated in the same horizon (the EF value for $\mathrm{Mn}=6.9$ is of the same order of that for $\mathrm{Co}=8.5$ ).

\section{CONCLUSIONS}

Soils of the Fernando de Noronha island developed from the highly alkaline and silica-undersaturated volcanic rocks of the Remédios and Quixaba Formations. The order of heavy metal abundances measured in these soils was: $\mathrm{Cr}>\mathrm{Ni}>\mathrm{Zn}>\mathrm{Co}>\mathrm{Cu}$. The un- 
usually high heavy metal concentrations of soils, generally well above the world averages, can be explained by the anomalous contents of these elements in the parent rocks, and the abundance of non-crystalline phases (particularly manganese and iron oxides and hydrous oxides) formed during pedogenesis.

The variations in the mineralogical and chemical composition among different soils can be interpreted as the result of variation in the composition of the lava flows. Soils developed from the nepheline basalts of the Quixaba Formation (MQ, SB, and MP sites) present higher $\mathrm{Fe}, \mathrm{Co}$, Ni and $\mathrm{Cr}$ contents than soils formed from the less mafic rocks of the Remédios Formation, corresponding to the $\mathrm{AB}$ site. These contain more $\mathrm{Si}$, $\mathrm{K}, \mathrm{Ba}, \mathrm{Sr}, \mathrm{Zr}$, Hf, and U. LB soils, developed under the influence of a more acid lithology, which is a body of alkaline trachyte (Remédios Formation), are the most enriched in $\mathrm{Cu}$ and $\mathrm{Zn}$ of all soils examined.

The geochemical variations within the examined profiles allowed to identify the role of manganese oxides and/or organic matter in the distribution of $\mathrm{Zn}$ and $\mathrm{Co}$, and, to a lesser extent, of $\mathrm{Cu}$ and $\mathrm{Ni}$. $\mathrm{Cr}$ is probably adsorbed or coprecipitated mostly with iron oxides and hydrous oxides. Heavy metals do not appear to show a significant affinity for clay minerals. In the MQ site, $\mathrm{Hg}$ concentrations found in the $0-30 \mathrm{~cm}$ horizon are one order of magnitude above those in the deeper horizons of the soil profile. Such accumulation is probably related to global long-range atmospheric transport and deposition of anthropogenic Hg. The affinity for organic matter could have further favoured the accumulation of $\mathrm{Hg}$ in the topsoil.

\section{ACKNOWLEDGMENTS}

The authors are particularly grateful to Dr. René Boulet and Dr. Heloisa Filizola for their helpful assistance in soil sampling. Dr. A. Siffedine and Prof. E. Menor are also acknowledged for participation in fieldwork. Financial support was provided by the Brazilian Agencies Fundação de Amparo à Pesquisa do Estado de São Paulo (FAPESP) and Conselho Nacional de Desenvolvimento Científico e Tecnológico (CNPq). We also want to acknowledge Jim Hesson for revising the English.

\section{RESUMO}

Este trabalho examina o papel da rocha parental, dos processos pedogenéticos e da poluição aerotransportada na acumulação dos metais pesados nos solos de uma ilha oceânica remota, Fernando de Noronha, Brasil. Foram estudados cinco perfis de solo desenvolvidos a partir de diferentes rochas vulcânicas. A composição mineralógica e as concentrações totais de elementos maiores e traços foram determinadas em 43 amostras. Os intervalos de concentração obtidos para os metais pesados foram: $\mathrm{Co}$ : 26-261 ppm; $\mathrm{Cu}: 35-97$ ppm; $\mathrm{Cr}$ : 350-1446 ppm; Ni: 114-691 ppm; Zn: 101-374 ppm; Hg: 2$150 \mathrm{ppb}$. A composição dos solos é fortemente afetada pelo caráter geoquímico da rocha parental. A pedogênese parece ser responsável pela acumulação de Zn, Co e, em menor grau, de $\mathrm{Ni}$ e $\mathrm{Cu}$, nos horizontes superiores dos perfis de solo, enriquecidos em Mn e em carbono orgânico. A influência pedogenética pode também explicar a relação observada entre $\mathrm{Cr}$ e Fe. $\mathrm{Hg}$ foi provavelmente adicionado ao solo por transporte atmosférico de longa distância. Sua acumulação no horizonte do topo do perfil de solo foi adicionalmente favorecida pela formação de complexos estáveis com a matéria orgânica. Os minerais de argila não parecem ter tido papel importante na fixação dos metais pesados.

Palavras-chave: metais pesados, solos, mercúrio antrópico, Fernando de Noronha.

\section{REFERENCES}

AlmeIda FFM DE. 1955. Geologia e petrologia do Arquipélago de Fernando de Noronha. Departamento Nacional da Produção Mineral - DNPM, Brasil, Monografia 13, 181p. (Unpublished).

BAize D And Sterckeman T. 2001. On the necessity of knowledge of the natural pedo-geochemical background content in the evaluation of the contamination of soils by trace elements. Sci Total Environ 264: 127-139.

Blaser P, Zimmermann S, Luster J AND SHotyk W. 2000. Critical examination of trace element enrichments and depletions in soils: $\mathrm{As}, \mathrm{Cr}, \mathrm{Cu}, \mathrm{Ni}, \mathrm{Pb}$ and $\mathrm{Zn}$ in Swiss forest soils. Sci Total Environ 249: 257-280.

CASARINI DCP, Dias CL AND Gaeta MN. 2001. Relatório de estabelecimento de valores orientadores para solos e águas subterrâneas no Estado de São Paulo, CETESB, $245 \mathrm{p}$.

Chen HM, Zheng CR, Tu C And ZHU YG. 1999. Heavy metal pollution in soils in China: status and countermeasures. Ambio 28: 130-131. 
CORDANi UG. 1970. Idade do vulcanismo do Oceano Atlântico Sul. Bol Inst Geoc Astron Univ S Paulo 1: 1-75.

FAO. 1990. Guidelines for Soil Profile Description. Third edition (revised). Soil Resources, Management and Conservation Service, Land and Water Development Division, FAO, Rome.

FitzGerald WF, ENGSTROM DR, MASON RP AND NATER EA. 1998. The case for atmospheric mercury contamination in remote areas. Environ Sci Technol 32: $1-7$.

GUNN BM AND WATKINS ND. 1976. Geochemistry of Cape Verde Islands and Fernando de Noronha. Geol Soc Am Bull 87: 1089-1100.

Hernandez L, Probst A, Probst JL and Ulrich E. 2003. Heavy metal distribution in some French forest soils: evidence for atmospheric contamination. Sci Total Environ 312: 195-219.

Horckmans L, SWennen R, Deckers J AND MaQuil R. 2005. Local background concentrations of trace elements in soils: a case study in the Grand Duchy of Luxembourg. Catena 59: 279-304.

Hylander LD AND Meili M. 2003. 500 years of mercury production: global annual inventory by region until 2000 and associated emissions. Sci Total Environ 304: 13-27.

Kabata-Pendias A And Pendias H. 1992. Trace elements in soils and plants. $2^{\text {nd }}$ ed., CRC Press, London, $413 \mathrm{p}$.

Lasheras Adot E, Plano ISC, Reixach JG AND VALENCIA DE. 2006. Geochemical inheritance of soils that develop from volcanic rocks (Navarra, Western Pyrenees). Geoderma 135: 38-48.

Lindberg S, Bullock R, Ebinghaus R, EngStron D, Feng X, Fitzgerald W, Pirrone N, Prestbo E, AND SEIGNeUR C. 2007. A synthesis of progress and uncertainties in attributing the sources of mercury in deposition. Ambio 36: 19-32.

LOPES RP AND UlBRich MNC. 2006 . Rochas vulcânicas da Formação Quixaba de Fernando de Noronha, PE: química mineral e litogeoquímica. Rev Bras Geoc 36(1): 35-48.

Manceau A, Llorca S And Calas G. 1987. Crystalchemistry of cobalt and nickel in lithiphorite and asbolane from New Caledonia. Geochim Cosmochim Ac 51: 105-113.

Mori Pe, Reeves S, Correia CT and HaukKa M. 1999. Development of a fused glass disc XRF facility and comparison with the pressed powder pellet technique at Instituto de Geociências, São Paulo University. Rev Bras Geoc 29(3): 441-446.

Nesbitt HW and Young GM. 1982. Early Proterozoic climates and plate motions inferred from major element chemistry of lutites. Nature 299: 715-717.

NRIAGU JO. 1989. A global assessment of natural sources of atmospheric trace metals. Nature 338: 47-49.

Oliveira SMB de, Pessenda LCR, Gouveia SEM, BABINSKI M AND FAVARO DIT. 2009. A geochemical and lead isotopic record in a small pond in a remote equatorial island, Fernando de Noronha, Brazil. Holocene 19(3): 433-442.

Palumbo B, Angelone M, Bellanca A, Dazzi C, Hauser S, Neri R AND Wilson J. 2000. Influence of inheritance and pedogenesis on heavy metal distribution in soils in Sicily, Italy. Geoderma 95: 247-266.

PESSENDA ET AL. 2008. Interdisciplinary paleovegetation study in the Fernando de Noronha Island (Pernambuco State), northeastern Brazil. An Acad Bras Cienc 80: 677691.

Reimann C, Arnoldussen A, Englmaier P, Filzmoser P, Finne TE, Garret RG, Koller F AND NordGULEN O. 2007. Element concentrations and variations along a $120-\mathrm{km}$ transect in southern Norway - Anthropogenic vs. geogenic vs. biogenic element sources and cycles. Appl Geochem 22: 851-871.

SALONEN VP AND KIRSTI KN. 2007. Influence of parent sediments on the concentration of heavy metals in urban and suburban soils in Turku, Finland. Appl Geochem 22: 906-918.

SCHLÜTER K AND GAETH S. 1997. Modelling leaching of inorganic $\mathrm{Hg}(\mathrm{II})$ in a Scandinavian iron-humus in a podzolvalidation and long-term leaching under various deposition rates. Water Air Soil Poll 96: 301-320.

Soubrand-Colin M, Bril H, Néel C, Courtin-NoMADE A AND MARTIN F. 2005. Weathering of basaltic rocks from the French Massif Central: origin and fate of $\mathrm{Ni}, \mathrm{Cr}, \mathrm{Zn}$ and $\mathrm{Cu}$. Can Mineral 43: 1077-1091.

Ulbrich MNC, Maringolo V AND Ruberti E. 1994. The geochemistry of alkaline volcanic-subvolcanic rocks from the Brazilian Fernando de Noronha Archipelago, South Atlantic Ocean. Geochim Brasil 3(1): 21-39.

Valle CM de, Santana GP, Augusti R, Egreja FB AND WindmolLER CC. 2005. Speciation and quantification of mercury in Oxisoil, Utisoil, and Spodosol from Amazon (Manaus, Brazil). Chemosphere 58: 779-792. 
WEAVER BL. 1990. Geochemistry of highly-undersaturated ocean island basalt suites from the South Atlantic Ocean: Fernando de Noronha and Trindade islands. Contrib Mineral Petr 105: 502-515.
WEDEPOHL KH. 1995. The composition of the continental crust. Geochim Cosmochim Ac 59(7): 1217-1232. 